\title{
ABSTRACT \\ How to Address Politics of the Body in Participatory Performance? On the Possibilities of Sensory Fields and Collective Body Techniques as Analytical Tools
}

This article discusses the importance of and challenges in analyzing and contextualizing the ways of bodily participation in participatory performance practic-

es. The writer suggests that the crucial ideological assumptions, as well as the processes of exclusion and inclusion of any participatory project, are not to be seen solely in their "goals" or "themes", but, even more distinctly, in the modes of bodily participation that they employ. The writer presents a novel performance analytical framework that takes the bodily dimension - what is actually done

to and expected from the bodies of the participants during the performance event - as the starting point for critical analysis. Drawing especially from Jacques

Rancière's and Marcel Mauss's views of human perception and experience, the main concepts of this framework are 'sensory fields' and 'collective body techniques'. The writer also shows how these concepts have informed his research on Lois Weaver's performance What Tammy Needs to Know About Getting Old and Having Sex (2008).

Keywords: performance analysis, performance philosophy, politics of the body, human perception, Jacques Rancière, Marcel Mauss.

BIOGRAPHY

Joonas Lahtinen is a performance researcher and artist based in Helsinki and

Vienna. He holds an MA in Performance from Queen Mary, University of London and an MA in Theatre Research from the University of Helsinki, where he is currently writing his PhD dissertation entitled Why Participate? 'Tammy WhyNot', 'Complaints Choir' and 'dominant powers. was also tun?'. Emancipatory Horizons and the Politics of Agency in Lois Weaver's, Tellervo Kalleinen's and Oliver Kochta-Kalleinen's and Claudia Bosse's Participatory Performance Practices. He has written several articles for Finnish research publications. His recent performances

have been shown in Austria, Finland, Germany, Switzerland and Romania. http:I/joonaslahtinen.wordpress.com, joonas.j.lahtinen@helsinki.fi 


\section{How to Address Politics of the Body in Participatory Performance?}

\section{On the Possibilities of Sensory Fields and Collective}

Body Techniques as Analytical Tools JOONAS LAHTINEN

\section{INTRODUCTION}

Participation is widely seen as one of the key factors in promoting equality, democracy, inclusion and collective action in most areas of society. Furthermore, a growing number of arts policy makers, artists, funding bodies, curators and theorists invest participatory performance practices with various therapeutic, pedagogical and overtly political goals. ${ }^{1}$ Recent research has shown that participatory art and performance practices entail ideological assumptions and exclusionary processes. For instance, Claire Bishop has concentrated on discourse analytical and institutional critique of historical and contemporary projects; Shannon Jackson on institutional and infrastructural dimensions of socially oriented practice; and Irit Rogoff and Florian Schneider on the problematic reliance on representation and identity in participatory art. ${ }^{2}$ However, relatively little attention has been paid to explaining the functioning of the human perceptual apparatus through which we sense and make sense of performance situations. Such explanatory efforts could open up new possibilities for interrogating and contextualizing the politics of the body in participatory practices. This would be more than welcome for many of us scholars and students for whom it is, as Colette Conroy suggests, "difficult to connect our theorising, spectating and acting with our cultural and scientific understanding of the shape and form of the body."
In this article, I present novel performance analytical tools that are grounded on a general view of human perception and signification processes and outline some of the ways in which they have informed my research on Lois Weaver's What Tammy Needs to Know about Getting Old and Having Sex (2008). I believe that the crucial ideological currencies and processes of exclusion and inclusion of any participatory project are not to be seen solely in their goals or themes but, even more distinctly, in the modes of bodily participation that they employ. My framework takes bodily participation - what is actually done to and expected from the bodies of the participants during the performance event - as the starting point for critical analysis. I share the belief in the entanglement of matter and meaning in all human experience - as well as the interest in the sensory and affective dimensions of human perception - with the so-called New Materialist approaches. ${ }^{4}$ Drawing especially from Jacques Rancière's and Marcel Mauss's views of human perception and experience, the main concepts of my framework are 'collective body techniques' and 'sensory fields'.

\section{PARTICIPATION, BODY AND POLITICS IN PERFORMANCE}

Definitions of participatory performance and of what passes as it depend on the context of use and the interests of the quarter that formulates them. ${ }^{5}$ 
The plausibility of the very term can also be questioned; as Jacques Rancière suggests, aren't all spectating, reading, and viewing activities related to art participatory by nature? ${ }^{6}$ Here, I define participatory performances as events that encourage or sometimes force the bodies of the participants to become visibly and audibly active and moving. Thus, their lowest common denominator is that they do not adhere to the conventional modern realist bourgeois theatre setting with its "illusion of the fourth wall", and in which the spectators sit still on their seats and watch the events on the stage silently from a seemingly objective position, as if "from a distance".

By the umbrella term 'politics of the body' in participatory performance, I refer to the bodily practices and distributions of agency, authorship and control: how are the participants addressed in a particular performance. What are they allowed, encouraged, or even forced to do? Furthermore, since participation necessarily implies processes of coming together and parting, what part(s) are the partakers offered in the performance. I agree with Michel Foucault that the human body is always "directly involved in a political field; power relations have an immediate hold upon it; they invest it, mark it, train it, torture it, force it to carry out tasks, to perform ceremonies, to emit signs" ${ }^{8}$ Indeed, the body, understood both as a material site and as a concept, plays a role in all human activity; in policy making as well as in our understandings of work, rights, freedom, jurisdiction and what it is to be a human being, starting from the very notion of "my" body, as Ed Cohen has pointed out. ${ }^{9}$

In my view, politics is not only about the "distribution of power across social relations, among different groups or classes or interests that make up, however momentarily, a social body" ${ }^{10}$ but also, and foremost, about who and what has a "part" in a social body in the first place. That is, politics is about the very practices of "ordering" reality; about the processes of making bodies, issues and things sensible and about fights and negotiations on having and not having a part and a share in a social body. Thus, politics is bound to the issue of participation right from the start. I share Davide Panagia's view that "our capacity to comprehend things is grounded in a particular organoleptic configura- tion [that] relate[s] our bodies to the world, but also determine[s] the conditions through and by which we might sense the world and those who occupy it [...]". ${ }^{11}$ It follows that sensing is a political activity since it organizes and guides our perception on a fundamental level: what is included in and what is excluded from our experience of reality. Artistic performances have the possibility to play with and challenge our experience of reality; who and what have a part in it. This is why they can be seen as having political currency.

\section{HUMAN PERCEPTION, SENSORY FIELDS AND COLLECTIVE BODY TECHNIQUES}

My view is predicated on the assumption that there is a specific sensory apparatus or mode in which the human organism, and many other organisms we call animals, register their surroundings. ${ }^{12}$ The term 'sensory field', which refers to forms, intensities and elements that the senses of an organism register amidst the continuous flux of stimuli that surround it, is a useful term to shed light on this mode. Here, "registering" does not refer to language-based acts of signification, but to acts of momentarily being affected by some elements in the ocean of stimuli that delineate and guide the perception of the organism. Erin Hurley describes affects as "uncontrollable, skin-level registration[s] of a change to our environment", as "sets of muscular and/or glandular responses" that make themselves known "through autonomic reactions, such as sexual arousal or sweating" and which "we cannot consciously control." ${ }^{3}$ Thus, affects are nothing that the organism could consciously choose but they refer to what just happens to engage its senses.

However, in human perception, sensory affects are automatically taken into language and turned into experiences of a self-conscious "I". ${ }^{14}$ Inspired by Karen Barad's thoughts, I believe that human perception is inevitably both material and discursive and that in our experience, nothing is only cognitive or only physical. ${ }^{15}$ For instance, thinking requires a material organ, the brain, and the fact that we can realize and name the 'brain' through language is cognitive work. This intertwining can be seen in the double meaning of 'sense': as Davide Panagia sug- 
gests, it can refer to both reflective activity ("what makes sense") and to sensory experience ("what can be sensed"). ${ }^{16}$

The processes of sensing and sense making of accessing and engaging with our surroundings through sensory fields and of automatically translating them into conscious experiences and thoughts can be illustrated by Jacques Rancière's term 'distribution of the sensible'. It refers to "the implicit law governing the sensible order that parcels out places and forms of participation in a common world by first establishing the modes of perception within which these are inscribed. The distribution of the sensible thus produces a system of self-evident facts of perception based on the set horizons and modalities of what is visible and audible as well as what can be said, thought, made, or done. Strictly speaking, 'distribution' therefore refers both to forms of inclusion and to forms of exclusion. The 'sensible', of course, does not refer to what shows good sense or judgement but to what is aisthèton or capable of being apprehended by the senses." 17

Every human being was born and lives in a specific social, political and historical situation within a particular distribution of the sensible that crucially informs the parameters of his or her worldview. Moreover, our experiences as members of a household within a distribution of the sensible inevitably affect our behaviour. We constantly assume and learn mimetic techniques to master various social situations both mundane and extraordinary; to survive within the social dramaturgy of the social body within which we live. Here, mimesis does not refer to the relationship between 'original' and 'copy', or to the relationship between language and a sensory experience as it does in representationalist theories. ${ }^{18}$ Instead, it refers to our capacity to learn and adopt behavioural patterns through observing and mimicking other people's behaviour both unconsciously and intentionally.

Drawing on Marcel Mauss's views, I call these behavioural patterns 'collective body techniques' so as to emphasize their bodily, social, technical and skill-bound dimension, yet these skills are not solely results of conscious training but also of our unconscious mimetic activity. Mauss was the first to use the concept 'techniques of the body'; he referred to them as "the ways in which, from society to society, men know how to use their bodies." ${ }^{19}$ The body is "man's first and most natural technical object, and at the same time his first technical means $[\ldots] "{ }^{20}$ Mauss emphasized that even our most essential activities such as walking, eating, sleeping and pushing have a body technical and "learnt" culture-bound character. ${ }^{21}$

Collective body techniques "embody" social norms in that they produce and manifest accustomed ways of using one's body "properly"; of reacting to other bodies "properly"; and of having a "proper" relation to one's own body in various social situations. They can be taught and imposed on individuals and groups purposefully in institutions such as schools, prisons, hospitals and museums but we also adopt them without noticing it. For instance, from our childhood on, we learn body technical routines and divisions of labour as to household chores; to the ways of behaving at home with other household members, guests and alone; as well as to ways of expressing and hiding feelings and emotions through facial and other bodily gestures. In a new or surprising social situation, we tend to automatically follow the way in which other people in that situation behave; I see this as an instance of unconscious mimetic learning. Also, the common pedagogical method of "teaching by example" relies on our mimetic capacity. ${ }^{22}$ Many of the body techniques that we encounter in our everyday life turn into parts of our habitus and identity. ${ }^{23}$

All communities involve behavioural codes or rules as to when their members are allowed to touch other bodies and objects and which situations are seen to require integrity. ${ }^{24}$ If a person does not succeed in learning the collective body techniques that are essential for recognition and acceptance as a member of the social body he or she lives in, he or she is likely to encounter social alienation, discrimination and violence. ${ }^{25}$ The same goes for instances where the person is not given an opportunity to learn these techniques or refuses to comply with them. 
SENSORY FIELDS AND COLLECTIVE BODY TECHNIQUES IN PERFORMANCE

Artistic performances do not stimulate their participants merely on the intellectual, reflective level but they also affect the participants' senses. Based on my view of human perception, I suggest that every performance gives rise to a particular sensory field, which in this context means the specific material, kinaesthetic, visual, aural and haptic situation created by the performance as a joint effect of all its participants and elements. It is through this sensory field that the participants form a conscious experience of the event. Since all sensory affects are automatically turned into experiences of a self-conscious "I", it follows that whenever we talk about or analyse a performance situation, we talk about our subjective experiences rooted in the sensory field opened up by that situation. It is not possible to describe sensory fields from an unbiased perspective.

The artists bring crucial elements to the sensory field by means of their actions and the scenography they have created - for instance, what they do and make visible and audible; where the participants are supposed to sit, stand or move about; what kind of ambience they try to generate and so forth - but they cannot take complete control of the sensory field of the event. This is due to the fact that sensory fields and the experiences that they arouse in participants are always situational; they depend on the specific bodily constellation, expectations, moods and reactions of each participant that cannot be fully predicted in advance. ${ }^{26}$ Indeed, any stimulus in the sensory field can engage the participants' senses; participants often register random stimuli such as cracks in the wallpaper, uncomfortable seats or the humming of the ventilation system. Sensory fields lead us away from thinking of agency as a human privilege or as merely intentional activity. Not only human participants, but also other sources can have agential force: sounds, noises and lifeless objects can affect participants, cause sensations in their bodies and attract their attention.

In performance situations, there are many collective body techniques and cultural codes of conduct at play that we are most likely to become aware of when someone or something breaks them. For instance, a child who attends a conventional theatre performance for the first time and who loudly comments on the actions on the stage has not yet learnt the "proper" behaviour in the theatre: that one is supposed to be silent and keep one's thoughts and reactions mostly to oneself while viewing the events on the stage. ${ }^{27}$

The transformative potential of participatory practices is often located in their striving toward promoting visible bodily activity among the partakers, the aim of which is to re-negotiate and challenge conventional or hegemonic ways of "being together" and of "proper" social interaction both in the art context and beyond. In principle, participatory performances can intervene with our senses and sensing in a very palpable manner. If politics is seen to be about (re)negotiations and fights for "getting a part", a say and visibility in the prevailing distribution of the sensible, participatory performances can have political relevance since they play and experiment with social processes of "having part" and they may thus invoke "breaches" in that distribution. In Rancière's words, an aesthetic experience can produce "a multiplicity of folds and gaps in the fabric of common experience that change the cartography of the perceptible, the thinkable and the feasible. As such, it allows for new modes of political construction of common objects and new possibilities of collective enunciation." ${ }^{28}$ That said, it should be borne in mind that artists often have a very clear and predefined vision of the desired form of participation and they give precise guidelines along which the participants are supposed or allowed to act in the performance situation. ${ }^{29}$

\section{SITUATION FRAGMENTS AND THE SUBJECTIVITY OF ANALYSIS}

All reflection and analysis of a performance is rooted in the kinaesthetic, sensory and bodily experiences of the researcher that guide his or her views and inform the choices he or she makes, both consciously and subconsciously. ${ }^{30}$ Writing about a performance is always a discursive and translational activity in which bodily experiences are verbalized. ${ }^{31}$ If we agree that experiences cannot be fully grasped through propositional language, and if we still want to do research based on such language, it is crucial to 
have an approach that recognizes this only partially attainable nature of experience through language. My framework is a move in this direction; I suggest that the sensory field opened up by the performance and the collective body techniques employed in it can be located with the help of 'situation fragments'. This term refers to written descriptions of specific sequences, scenes and spatial arrangements in the performance that have left strong traces in the researcher's memory, as well as to the ambiences and feelings that the performance has aroused in him or her as a participant of the live event; as a viewer of video documentation; or, say, as a reader of newspaper reviews. Research that is based on situation fragments does not aim at an all-encompassing description of the research object. Instead, it recognizes the subjective and, to a certain extent, "indescribable" and fragmentary nature of perception.

\section{ON APPLYING MY FRAMEWORK TO PRACTICE: WHAT TAMMY NEEDS TO KNOW ABOUT GETTING OLD AND HAVING SEX}

Lois Weaver's performances have been analyzed from "affirmative", or, in Jill Dolan's terms, "passionate" perspectives that have emphasized their empowering, counterhegemonic and community-building possibilities. ${ }^{32}$ Next, I will briefly outline how my framework has also helped me locate exclusive tendencies regarding the politics of the body and ideological currencies that underlie Weaver's What Tammy Needs to Know About Getting Old and Having Sex (2008). The performance aimed to engage its participants - spectators of different ages, including medical students ${ }^{33}$, a professional sexologist, a few elderly female Londoners as Weaver's co-performers and Weaver herself - in a discussion about sexual desires and personal experiences, especially concerning the effects of ageing on sexuality and having sex. The core of the performance was Weaver's alter ego persona Tammy WhyNot - "a country ' $n$ ' western star turned lesbian performance artist" 34 - who is a means of facilitating engagement and public dialogue about issues that are "often burdened by social assumptions and myths". ${ }^{35}$ I saw the performance at the John Ellis Lecture Theatre of the Royal London Hospital, Whitechapel on 17
November 2008 as part of the Performing Medicine project that "uses methods found in the arts to help medical students and health professionals develop skills essential to clinical practice and healthcare". ${ }^{36}$

The sensory field of the performance - including the spatial and architectural setting, participants and their actions and the ambience - was dominated by a classroom-like spatial arrangement: in the low-roofed room, the spectators were placed in rows of uncomfortable chairs, each row having a long writing surface that emphasized the separation between the audience and the strongly lit stage area in the front area of the room. For the most part of the performance, the audience were assumed to adopt the body technique familiar from conventional theatre performances, that is, to sit attentively next to each other and watch Weaver-as-Tammy perform in the limelight, telling anecdotes, interviewing the elderly women and dancing with them as well as discussing sex problems with the sexologist on stage. Throughout the performance, there were giggling and bursts of laughter in the audience, as well as sounds of chairs squeaking under the spectators' weight. The ambience brought about by the sensory field reminded me of a sex education class at an upper school, Weaver-as-Tammy being the teacher and the audience her pupils.

This ambience was intensified due to the main participatory body technique: verbalizing and talking aloud about sex-related issues. In the scene that I remember particularly well and that I use as one of the key situation fragments in my research, Weaver-as-Tammy gave every spectator a piece of paper, each of which had an unfinished sentence relating to sex such as "If I had a secret sex life..." and then started to go around among the audience to ask individual spectators how they would continue the sentence intuitively, looking them keenly in the eyes and repeating some of the answers via her microphone. A few spectators stayed quiet or hesitated, blushing and looking visibly embarrassed and uncomfortable on their seats as Weaver-as-Tammy came to them. She smiled naughtily and waited by many of these spectators until they said something aloud, or came back to them after a while to ask the same question again. That is, uncooperative spectators were harassed to put their thoughts into 
words and share them with the others as if they were underachieving pupils in a school homework interrogation.

Weaver's insistence on making the spectators talk aloud added a therapeutic aspect to the ambience. Verbalization and speech appeared here as a medium of exploring, recognizing and processing one's own - and the other participants' - sexual imaginations, desires and bodily sensations through language, as if the spectators were taking part in a group therapy session led by Weaver-as-Tammy, each of them letting their thoughts out in turns. The performance seemed to rely on the assumption that we can make a "sensible" project out of sexuality and sex practices and thus, it seems to adhere to the "therapeutic aesthetic" whose objective "is to mobilize and modify consciousness, to create a sustainable and self-regulating psychic project out of very complicated human feelings" ${ }^{37}$

Weaver believes in the empowering function of talking in public; she is "committed to both audibility and visibility" and the democratic principle that "everyone deserves a voice $[. .$.$] ". { }^{38}$ Indeed, the performance gave visibility and voice to the elderly women: onstage they could show to younger spectators - many of who were medical students that they are active and energetic individuals and not a passive, monolithic group of the population. Through their songs, energetic dances and interviews that Weaver-as-Tammy carried out with them, these co-performers made it clear that although they may look different and act differently from the younger people, they also move about and have sexual needs and desires. Their acts may have invoked "breaches" in the distribution of the sensible as to the ways in which the other participants perceive elderly people and their needs, and regarding the ways of talking about sex and sexuality in various situations: with the doctor, with one's family members and friends, and so forth. Furthermore, the performance may have inspired some of the spectators to rethink their views of sexuality or to become more adventurous in their sex lives.

Concerning the politics of the body - what possibilities for bodily agency were offered to the participants - there were two significantly different agential roles to be seen. The elderly women with whom
Weaver had planned and rehearsed dance and song numbers and prepared short live interviews to be staged in the show, knew what they and their bodies were expected to do in the live performance situation. The spectators, on the contrary, were urged - and forced - to verbalize their thoughts and speak them out at Weaver's request without prior notice and without asking their consent. That is, Weaver's participatory strategy deprived the spectators of their right to keep silent. In the performance, being introverted, shy or just reluctant appeared as an "inhibition" that needed to be cured. What is more, sexuality - and the belief that we can learn to enjoy it more through facilitated taboo-breaking speech was in the performance conveyed as a given fact; the spectators were addressed as if sexuality was self-evidently a central part of their lives, and as if they would undoubtedly benefit from the verbalizing and voicing acts that were demanded from them. Weaver seemed to impose her view of reality and identities - in which sexuality, being extrovert, and making one's views and claims public are central issues - on the spectators. Thus, Weaver's participatory strategy can be seen as exclusionary from the point of view of shy and introvert spectators, by spectators in whose lives sex and sexuality do not play a central role and who do not adhere to the therapeutic ethos, as well as by spectators who had simply wished for more freedom in deciding if and how they participate in the performance.

\section{CONCLUSION AND FUTURE PROSPECTS}

In this article, I have presented novel performance analytical tools - 'sensory fields' and 'collective body techniques' - that offer an explanation of how we sense and make sense of performance situations and of reality. I have also briefly shown how these tools have helped me shed light on potential exclusions and underlying assumptions in Lois Weaver's What Tammy Needs to Know About Getting Old and Having Sex, such as the participatory strategy that forced the spectators to be extrovert and talk aloud; the therapeutic and pedagogical tendencies; and the unquestioned reliance on sexuality. While I do recognize the significance of "affirmative" and "passionate" research for feminist and other perfor- 
mance projects, I believe that novel tools - such as those that I have presented here - can provide useful inputs for scholars and artists alike to further develop our critical practice.

The concepts 'sensory fields' and 'collective body techniques' can also be applied to other types of research that focus on the relation between the aims of a project - artistic or other - and on what actually takes place during its execution process. They may prove to be especially relevant to such disciplines as policy studies, urban studies, architectural theory and disability studies, as well as to scholars of epistemology and critical ontology. While I have not been able to present all aspects of my framework within the scope of this article, I hope that it will inspire other scholars interested in politics of the body and participatory practices to further develop and critically apply it to their research. 


\section{NOTES AND REFERENCES}

1 Participation has been a key topic in the critical discourse on the modes and social and political 'efficacy' of art and performance practices since the 'social turn' in the 1990's that Claire Bishop describes as "a shared set of desire to overturn the traditional relationship between the art object, the artist and the audience" (Claire Bishop, Artificial Hells. Participatory Art and the Politics of Spectatorship, Verso, London and New York 2012, p. 2). Nicolas Bourriaud's 'relational aesthetics' is arguably the most debated recent approach to participatory practice; he claims that certain participatory artworks can "re-stitch the relational fabric" and that " $\mathrm{t}]$ hrough little services rendered, the artists fill in the cracks in the social bond". (Nicolas Bourriaud, Relational Aesthetics, Les presses du réel, Paris 2002, p. 36.) On the critiques of Bourriaud's views and on the harnessing of participatory art to financial, social and culture policies, see e.g. Jen Harvie, Fair Play. Art, Performance and Neoliberalism, Palgrave Macmillan, Basingstoke 2013; Shannon Jackson, Social Works. Performing Art, Supporting Publics, Routledge, London, New York 2011; Markus Miessen, The Nightmare of Participation. Crossbench Praxis as a Mode of Criticality, Sternberg Press, Berlin, New York 2010.

2 Bishop interrogates what she views as "the unhelpful binary of 'active' and 'passive' spectatorship, and [...] the false polarity of 'bad' singular authorship and 'good' collective authorship" and hopes "to generate a more nuanced (and honest) critical vocabulary with which to address the vicissitudes of collaborative authorship and spectatorship". (Bishop, op. cit., p. 8). Jackson argues for "systemic relationality", "inter-dependency", "support" and "infrastructural avowal" that might offer an alternative to the system-critical and anti-institutional ethoses in art-making and research that all too easily - unwantedly - comply with Neoliberalist policies. (See Shannon Jackson, "Working Publics" in Performance Research, vol. 16, no. 2, 2011, pp. 8-13; Jackson, Social Works, op. cit., pp. 23-4, 35-6, 42.) Rogoff and Schneider shape a novel approach to participation, a conceptual shift that they call "productive anticipation." Breaking up with the representationalist mode of perceiving power and subject positions, "productive anticipation" is "a state which is both reflective and participatory but not one of indications and navigations, not one that tries to didactically point to where one might look and what one might see". (Irit Rogoff and Florian Schneider, "Productive Antic- ipation" in Cultural Politics in a Global Age. Uncertainty, Solidarity and Innovation, David Held, Henrietta L. Moore, eds., Oneworld, Oxford 2008, p. 347.) Drawing on Giorgio Agamben, Rogoff and Schneider employ the term 'singularity' that is, for them, "another mode of relationality, another possibility of building community, not around a shared set of claims but rather around the sharing of momentary proximities and affiliations". (Ibid., p. 354.) They highlight the political and social currency that the "unforeseeable, unpredictable, uncalculable" entailed in "productive anticipation" may have by providing us with new possibilities to "have access" to art and to intervene in the production of meaning and agency. (Ibid., p. 350-3.)

3 Colette Conroy, Theatre and the Body, Palgrave Macmillan, Basingstoke 2010, pp. 7-8.

4 See e.g. New Materialism: Interviews \& Cartographies, Rick Dolphijn, Iris van der Tuin, eds., Open Humanities Press, Ann Arbor 2012, pp. 90-1.

5 See Bishop, op. cit., pp. 1-2, 13-18; Helen Freshwater, Theatre \& Audience, Palgrave Macmillan, Basingstoke 2009, pp. 75-6; Miessen, op. cit., pp. 43-57. Miessen addresses the problematic uses of "participation" in formal politics and architecture in a manner relevant to performance research.

6 Jacques Rancière, “The Emancipated Spectator" in Artforum, March 2007, pp. 277-8. See also Harvie, op. cit., p. 30.

7 William B. Worthen, Modern Drama and the Rhetoric of Theater, University of California Press, Berkeley, Los Angeles 1991, pp. 5-6, 17. See also Harvie, op. cit., pp. 5-6.

8 Michel Foucault, Discipline and Punish: The Birth of the Prison, Vintage, New York 1977, p. 25.

9 Ed Cohen, "A Body Worth Having?: Or, A System of Natural Governance" in Theory, Culture and Society, vol. 25, no. 3, 2008, pp. 103-29. See also Conroy, op. cit., p. 16.

10 Joe Kelleher, Theatre \& Politics, Palgrave Macmillan, Basingstoke 2009, p. 3.

11 Davide Panagia, The Political Life of Sensation, Duke UP, Durham, London 2009, p. 7. For organolepsis, see ibid., pp. 151, 155 (footnote 3).

12 I do not wish to propose a universalistic view of a human subject; instead, I aim to offer a plausible account of the perceptual apparatus within which our self-understandings and any subject assumptions can arise. 
13 Erin Hurley, Theatre \& Feeling, Palgrave MacMillan, Basingstoke 2009, p. 13. See also Brian Massumi, "Kräfte des Widerstands. Ideologie und Affekt" in springerin, no. 2, 2013, pp. 39-43.

14 That said, "for the infant affect is innate. Through facial expression, respiration, posture, color, and vocalisations infants are able to express the intensity of the stimulations that impinge upon them [...] The transition from childhood to adulthood is one in which we partially learn how to bring the display of emotion under conscious control." (Eric Shouse, "Feeling, Emotion, Affect" in M/C Journal, vol. 8, no. 6, 2005, paragraph 6, http:// journal.media-culture.org.au/0512/03-shouse.php (accessed 15 August 2015).)

15 According to Barad, "materiality is discursive (i.e., material phenomena are inseparable from the apparatuses of bodily production: matter emerges out of and includes as part of its being the ongoing reconfiguring of boundaries), just as discursive practices are always already material (i.e., they are ongoing material (re)configurings of the world)". (Karen Barad, "Posthumanist Performativity: Toward an Understanding of How Matter Comes to Matter" in Signs: Journal of Women in Culture and Society, vol. 28, no. 3, 2003, p. 822.)

16 See Panagia, op. cit., p. 3.

17 Gabriel Rockhill, "Appendix I. Glossary of Technical Terms" in Jacques Rancière, The Politics of Aesthetics, Continuum, London, New York 2006, p. 85. Rancière states that "the distribution of the sensible is not an ideological machine or the disciplinary rule [but] the play of relations between the visible, the sayable, the thinkable and the doable at the heart of which gazes operate, things are named, discourses produced, actions undertaken." (Jacques Rancière, "Against an Ebbing Tide: An Interview with Jacques Rancière" in Reading Rancière, Paul Bowman, Richard Stamp, eds., Continuum, London, New York 2011, p. 242.)

18 On representationalism and its problems, see Barad, op. cit., pp. 803-11.

19 Marcel Mauss, "Techniques of the Body" in Incorporations, Jonathan Crary, Sanford Kwinter, eds., Zone Books, New York 1992, p. 455. I have some critical reservations regarding Mauss's views. He over-emphasizes the self-reflective and conscious acts of learning and adopting body techniques (ibid., pp. 459, 464). Furthermore, I do not agree with Mauss on that body techniques would be principally "divided and vary by sex and by age" (ibid., p. 462, italics in the original). What is more, Mauss implies that women are weak and cannot throw as well as men do (ibid., p. 463). These beliefs may be exemplary of the binary and patriarchal ethos reigning in the academic discourse at the time of Mauss's writing in 1934-35 but they are untenable from my perspective.

20 Ibid., p. 461.

21 Ibid., pp. 458, 465-73.

22 Ibid., pp. 464-7. See also Roger Deacon, "Michel Foucault on Education: a Preliminary Theoretical Overview" in South African Journal of Education, vol. 26, issue 2, 2006, pp. 177-87. For a concise analysis of the museum as a behaviour-regulating institution, see Tony Bennett, The Birth of the Museum. History, Theory, Politics, Routledge, London, New York 1995, pp. 100-3.

23 I understand habitus broadly as lifestyles, values, dispositions and expectations that we acquire through our everyday activities. However, as beings capable of reflection, we do not automatically adopt all body techniques we encounter but can partly assess and mould them, and consciously decide on what body techniques we adopt to our habitus and lifestyle. See Mike Featherstone, "Lifestyle and Consumer Culture" in Theory, Culture and Society, vol. 4, no. 1, 1987, p. 64. See also Mauss, op. cit., p. 458.

24 See Esa Kirkkopelto, "Mimesiksen kosketus" in Kosketuksen figuureja, Mika Elo, ed., Tutkijaliitto, Helsinki 2014, pp. 96-7. See also Cohen, op. cit., pp. 103-4.

25 The human body is vulnerable and, thus, always at risk of becoming mimetically "incapable", i.e. of losing the characteristics that make the person recognisable to others as a "normal" human being. Petri Tervo calls the states of being cut off from the mimetic and gestural community as states of being a 'bodypart' (in Finnish 'ruumiskappale'). These states can result from acts of violence and political terror, as well as from illnesses and accidents. (See Petri Tervo, Kirurgisen operaation teatteri. Teatterillinen kuva ja ihmismuodon esitettävyys avantgardistisen väkivallan näkökulmasta, Doctoral Dissertation in Theatre Research, University of Helsinki, Helsinki 2006, p. 15.)

26 See Freshwater, op. cit., pp. 5-6.

27 However, since the 'social turn', participatory performance practices have brought about their own "mainstream" collection of participatory strategies - which also have historical precedents - that many participants 
expect to encounter in the performance. (See Bishop, op. cit., pp. 2-5; Harvie, op. cit., pp. 29-61.)

28 Jacques Rancière, "Aesthetic Separation, Aesthetic Community: Scenes from the Aesthetic Regime of Art" in ART \& RESEARCH: A Journal of Ideas, Contexts and Methods, vol. 2, no. 1, 2008, PDF version, p. 11, http:// www.artandresearch.org.uk/v2n1/pdfs/ranciere.pdf (accessed 15 August 2015). For Rancière's view of politics, see Jacques Rancière, "The Thinking of Dissensus: Politics and Aesthetics" in Reading Rancière, Paul Bowman, Richard Stamp, eds., Continuum, London, New York 2011, pp. 1-7.

29 See Freshwater, op. cit., pp. 75-6; Rogoff and Schneider, op. cit, pp. 352-3.

30 In addition, the ways of using language and one's body "properly" in social situations - which the researcher has learnt by living as part of a specific household and social body within a certain distribution of the sensible - affect the ways in which he or she makes sense of and analyses the performance.

31 See Marja Silde and Petri Tervo, "Esitys ja ekphrasis: eli kuinka kuvata esiin luuranko esityksen kaapista" in esitys, no. 1, 2014, p. 35. For a concise definition of discourse in Foucault's sense, see Stuart Hall, "The West and the Rest: Discourse and Power" in Formations of Modernity, Stuart Hall, Bram Gieben, eds., Polity Press, Cambridge 1992, p. 291.

32 See Jill Dolan, "Performance, Utopia, and the 'Utopian Performative" in Theatre Journal, vol. 53, 2001, pp. 478-9; Jill Dolan, "Feminist Performance and Utopia: A Manifesto" in Staging International Feminisms, Elaine Aston, Sue-Ellen Case, eds., Palgrave Macmillan, Basingstoke 2007, pp. 214-6. For examples of affirmative research perspectives on Weaver's work, see e.g. Sue-Ellen Case, Split Britches. Lesbian Practice/Feminist Performance, Routledge, London, New York 1996; The Only Way Home is Through the Show. Performance Work of Lois Weaver, Jen Harvie, Lois Weaver, eds., LADA and Intellect, London, Bristol 2015; Joonas Lahtinen, “Reflections on Identity Politics, 'making together' and Public Engagement in Lois Weaver's Tammy WhyNot Performances" in Näyttämöltä tutkimukseksi. Esittävien taiteiden metodologiset haasteet, Liisa Ikonen et. al., eds., Teatterintutkimuksen seura, Helsinki 2012, http://teats. fi/TeaTS4.pdf (accessed 15 August 2015).

33 Weaver pointed this out in the beginning of the performance.
34 Jen Harvie, "Places to Start" in The Only Way Home is Through the Show, op. cit., p. 30. On the history of Tammy WhyNot, see e.g. Lisa Duggan, "A Woman Disguised as a Woman: Lois Weaver's Fem(me)inist Performances" in ibid., p. 105.

35 Jen Harvie, “Tammy WhyNot: Stage/life Superhero" in The Only Way Home is Through the Show, op. cit., p. 239. Weaver's and Split Britches' performance characters are combinations of various "layers" of identity that draw e.g. from the performer's autobiographical experiences and her identification with a popular culture star. For Weaver's performance devising method, see e.g. Sue-Ellen Case, op. cit., pp. 9-11; Lois Weaver, "Tammy interviews Lois" in The Only Way Home is Through the Show, pp. $221-7$.

36 http://performingmedicine.com (accessed 15 August 2015). Due to their emphasis on audience participation, Weaver's Tammy WhyNot performances vary significantly from place to place. Here, I discuss only the performance I attended.

37 Ricky D'Ambrosio, "The Aesthetic and the Therapeutic" in The Brooklyn Rail. Critical Perspectives on Arts, Politics and Culture, December 2011, section 6, http://brooklynrail.org/2011/12/film/the-aesthetic-and-the-therapeutic (accessed 15 August 2015). See also Fintan Walsh, Theatre \& Therapy, Palgrave Macmillan, Basingstoke 2013, pp. 1-6; Valerie Walkerdine, "Therapy” in New Keywords. A Revised Vocabulary of Culture and Society, Tony Bennett et. al., eds., Blackwell, Malden (MA) 2005, pp. 349-51.

38 Weaver, op. cit., p. 221; Lois Weaver and Caoimhe McAvinchey, "Lois Weaver: Interview and Introduction by Caoimhe McAvinchey" in Performance and Community: Commentary and Case Studies, Caoimhe McAvinchey, ed., Bloomsbury, London 2014, p. 29. 
